\title{
EMPLOYMENT OF STUDENTS IN HIGHER EDUCATIONAL STUDY COMPARED TO NORMAL REGULATION OF EMPLOYMENT
}

\author{
L. E. Piskunova, T. O. Zubok, B. V. Kislytsky
}

National University of Life and Environmental Sciences of Ukraine, Ukraine.

Corresponding authors: tanyzubok@gmail.com.

Article history: Received: March 2019. Received in the revised form: April 2019. Accepted: August 2019.

Bibl. 23, fig. 0, tabl. O.

Abstract. Some of the most widespread situations are discussed, which in practice often raise the question: to take a student of full-time part-time or consider the company as the main place of his work, who and how will conduct a work book.

During studying between full-time students and educational institutions, there is no employment relationship and no employment contract. Therefore, such training is not the main work of the student.

Minor student workers have the same labor rights and responsibilities as other employees.

The full and shorter duration of a working week is established by a collective agreement depending on the results of the certification of workplaces in accordance with the Procedure for conducting certification of workplaces under labor conditions, approved by the Cabinet of Ministers of Ukraine from 01.08.92, No. 442.

Key words: the Labor Code of Ukraine, the State Department for Labor Legislation Supervision, the Instruction of the procedure for conducting labor books, labor legislation, work under an employment contract, a work record, a combination of work, a monetary expression, the employment of minors.

\section{Introduction}

The development of science and technology, the latest technology requires highly skilled workers. Therefore, today the situation when a student begins to work before the end of the educational institution on many sides is justified. Especially if a student works in a specialty. Also, given the socio-economic situation in the country, when parents are no longer able to help children-students, young people are forced to seek employment. And more and more often there are issues of a legal nature regarding the regulation of labor relations with students who combine work with study.

\section{Formulation of problem}

Several widespread situations are considered, which in practice often cause law questions regarding the regulation of labor relations with students who combine work with study.
To accept a student of full-time education on a parttime work or to consider the enterprise the main place of his work? The question is fundamental, as it is related to the conduct of a work book.

The clarifications provided by the State Department for the Supervision of Compliance with Labor Law have changed year by year. The Department substantiates the position that full-time students can be hired only on a conditional basis. This opinion is based on the Law of Ukraine "On Employment of the Population", which stipulates that persons studying in secondary schools and higher educational establishments are in work persons.

Based on the latest explanations normative regulation of employment of day-care students, the main points of the state regulation of the employment of students are highlighted.

The current labor law does not contain a definition of the concept of the main place of work or part-time work. However, the work of a student who attends full-time study forms can not be considered as part-time. As for full-time students, during the studying between them and educational institutions there is no employment relationship and no employment contract. Therefore, such studying is not the main work of the student.

Minor student workers have the same labor rights and responsibilities as other employees. However, when employing first-year students, employers must monitor whether there are among them minors who are provided with special employment and labor requirements.

Article 45 of the Constitution of Ukraine stipulates that the worker is guaranteed the length of working time established by law. Law relations, which determine the length, composition, mode and procedure for recording working time, are regulated by the Labor Code of Ukraine (hereinafter - the Labor Code) and other normative-legal acts.

\section{Purpose of research}

The purpose of the paper is to consider some of the most common situations, which in practice often raise questions, as well as suggest some recommendations, taking into account the unresolved law relationship in this matter. 
Firstly, an explanation regarding the normative regulation of the employment of full-time undergraduate students, which existed during the last ten years.

The first question that arises immediately is to take a student of full-time part-time or consider the company as the main place of his work. The question is fundamental, since it is connected with the conduct of the labor book, and the Code of Labor Laws of Ukraine (hereinafter - the Labor Code) does not give a concrete answer, moreover, it does not mention it at all.

\section{Results of research}

Article 43 of the Constitution of Ukraine defines the right of every citizen to work, including the possibility of earning a living for work, which he freely chooses or freely agrees to. In accordance with Article 2 of the Labor Code, the state guarantees the right of citizens to work. For the work performed by the employee (citizen), the owner or his authorized body pays his salary - a remuneration, calculated, as a rule, in monetary terms (Article 94 of the Labor Code, Article 1 of the Law of Ukraine "About payment of labor" dated March 24, 1995, No. 108/95 -BR)

In pp. 7 clause 1 of Art. 1 Law of Ukraine "On Employment of the Population" dated 05.07.2012 No. 5067-VI (hereinafter - the Law № 5067-VI) stipulates that employment is not prohibited by law the activities of persons connected with the satisfaction of their personal and social needs in order to receive income (wages) in monetary or other form. And according to Part 1 of Art. 4 Publication No. 5067-VI also covers the number of fulltime students enrolled in higher education and combines work with the work. In addition, the Law of Ukraine "On Education" dated May 23, 1991 No. 1060-XII (Part 14, Clause 1, Article 51) and the Law of Ukraine "On Higher Education" dated July 1, 2014, No. 1556-VII (clause 3, p. 1 item 62) students have the right to work in accordance with the established procedure at extra-curricular time.

In subparagraph 7 paragraph 1 of art. 1 Law of Ukraine "On Employment of the Population" dated 05.07.2012 No. 5067-VI (hereinafter - the Law № 5067VI) stipulates that employment is not prohibited by law the activities of persons connected with the satisfaction of their personal and social needs in order to receive income (wages) in monetary or other form. And according to Part 1 of Art. 4 Publication No. 5067-VI also covers the number of full-time students enrolled in higher education and combines education with work. In addition, the Law of Ukraine "On Education" dated May 23, 1991 No. 1060-XII (Part 14, Clause 1, Article 51) and the Law of Ukraine "On Higher Education" dated July 1, 2014, No. 1556-VII (clause 3, p. 1 art. 62) students have the right to work in accordance with the established procedure at extracurricular time.

The current labor law does not contain a definition of the concept of the main place of work or part-time work. However, the work of a student who attends full-time study forms can not be considered as part-time. After all, in accordance with clause 1 of the Regulations on the conditions of work of the part-time employees of state enterprises, institutions and organizations, approved by a joint order of the Ministry of Labor, Ministry of Justice and the Ministry of Finance of 28.06.1993 number 43, parttime is considered to be an employee thet has, except his main, other regular paid work on the terms of an employment contract, the time off from the main work at the same enterprise, institution, organization or citizen (entrepreneur, private person) for hire.

The right to work for an employee is realized through the conclusion of an employment contract on work in an enterprise, an institution, an organization or with an individual (Article 2 of the Labor Code). As far as full-time students are concerned, during the studying between them and the educational institutions (in this case, between the National University of Life and Environmental Sciences (hereinafter - NUBiP)) there is no employment relationship and no employment contract. Therefore, such studying is not the main work of the student. Consequently, his work (in the case of employment) can not be regarded as being performed in addition to his main work, that is, a combination. In addition, the position that the work of an employment contract of persons who combine it with a full-time form of study is not a part-time, is set forth in the letter of the Ministry of Social Policy from 05/25/2015 № 198/06 / 186-15. It actually referred to paragraph 3 of paragraph 14 of the Verkhovna Rada of Ukraine "On the Practice of the Use of Labor Legislation by the Courts" of December 24, 1999, No. 13, which stipulates that work under an employment contract of persons who combine it with a full-time form of study, is not part-time and is paid on a general basis. The same position is set out in the letter of the Ministry of Social Policy of Ukraine dated July 25, 2014 № 301/13 / 116-14 concerning the recruitment of students. It states, in particular, that labor laws do not provide for restrictions on the combination of university students, including those studying in full-time (full-time) forms of study, work and education. Therefore, the employer has the right to employ such employees, including on a full-time basis. Consequently, the work of an employment contract of persons who combine it with full-time education is not a part-time job, and therefore involves keeping a work record in accordance with the general procedure and is the main place of work for such persons.

The question would not be so ambiguous if universities were obliged to keep work books (if any) or to open them to students who did not have a seniority before entering the university. Therefore, each educational institution decides on the issue of a work book at its discretion: some require it from the students (if any), while others are not interested at all whether the student worked before entering the university and whether he has a work record. In NUBiP Ukraine, these issues are solved by all regulatory documents. Upon entering the university, if the student presents a work book with preliminary records, the work book remains in the student's personal affair, and in the case of a student's employment, all entries are made by the higher education institution, according to paragraph 2.16 of the Instructions: "For students, students of courses, students, postgraduates and clinical residents who have work books, the educational institution (scientific institution) makes recordings about the time of study in day-time departments (including preparatory) of higher educational establishments. The reason for such records is the orders of the educational institution (scientific 
institution) about admission to studies and deductions from among students, students, postgraduate students, clinical residents. "We will not dwell on the issue of another algorithm for calculating the scholarship.

If a student of full-time study at a job tells that he has submitted a work book to an educational institution, then it is more likely to be more convenient for him to hire a job on the terms of conciliation. However, this issue can also be dealt with differently depending on the circumstances. So, if you are obliged to apply for a work-book at the entrance to an educational institution (if it is available), then get it back, as mentioned above, it will be possible only after the completion of the training. In this case, the student is better off to work for a part-time job.

If the educational institution does not require a workbook, but accepts it on the initiative of the apprentice, then there is no hurry to record the study record there. This is especially true for non-state educational institutions whose students do not receive scholarships and, as a rule, begin to work at the first courses of study. Based on the interests of the student, such schools can give a work book (of course, if there is no record of entry into the studies), realizing that the record of training they can do at any time, and the student who works at the enterprise as the main the place of work, in the future there will be reasons to rely on social benefits (for example, it will affect the size of the payment card disability). Here, only from the employer and the student will depend on what conditions the latter will be employed.

We want to stay isolated on the employment of minors. Students, that work, have the same labor rights and responsibilities as other employees. However, when employing first-year students, employers must monitor whether there are among them minors who are subject to special employment and labor requirements.

Yes, Art. 50 Labor Code provides that the normal working hours of workers cannot exceed 40 hours per week. Part two of this article allows the possibility of establishing collective time agreements at enterprises and organizations with less duration of working time.

The guarantees provided by the legislator concerning the maximum length of working time apply to hired employees of enterprises of all forms of ownership. In accordance with Article 51 of the Labor Code, the reduced working hours are set:

- For workers aged 16 to 18 years - 36 hours a week, for people aged 15 to 16 (students aged 14 to 15 working during the holidays) - 24 hours a week. For students who work during the school year in their free time, the duration of working time cannot exceed half the maximum duration of working time provided for in par. 1 of this item for persons of the corresponding age;

- for workers employed in work with harmful working conditions - no more than 36 hours per week. The list of manufactures, shops, professions and positions with harmful working conditions, the work of which gives the right to a shorter working week, is determined by the decision of the Cabinet of Ministers of Ukraine of 21.02. 2001 No. 163.

It should be borne in mind that, in accordance with the order of the Ministry of Labor and Social Policy of Ukraine of 23.03.2001 №122, the reduced duration of the working week is established by a collective agreement depending on the results of certification of workplaces in accordance with the Procedure for conducting certification of workplaces under the terms of work, approved by the decree Cabinet of Ministers of Ukraine from 01.08.92 № 442.

At the same time, it should be noted that a student who studies in a permanent (special) department of an educational institution can perform his / her duties only during his / her free time:

on weekdays - after classes (in the evening or during "windows" in the schedule of classes), on weekends or during the holidays.

Students who are studying on an individually defined schedule must make sure that there is no "overlap" with the time of individual training or examinations. Therefore, in our university, students who translate into an individual chart receive a paper version of an individual chart and, as a matter of necessity, bypass teachers, receive tasks, and determine the time of attestation. With the introduction of the MOODLE distance learning at the university, it was much easier to learn from an individual curriculum, and to teach and supervise the learning process.

In Part 1 of Art. 56 of the Labor Code defined that an agreement between the employee and the owner or the body authorized by him may be established both during hiring and subsequently part-time or part-time working weeks, and in Part 2 of this article it is established that wages in these cases is carried out in proportion to the time worked or depending on the output. That is, the mode of work of students will depend on the schedule of studying, and the payment of labor - on the duration of the performance of labor duties.

Part-time can be set as: part-time working day (ie, reducing the duration of daily work for a predetermined number of hours); part-time working week (in which the normal working day is maintained, but the number of working days per week decreases); a combination of parttime working day and part-time working week (for example, a working day of 5 hours at 4 working days per week).

Please note that part-time work can be set after an employer's and student's agreement for a certain period or without a time limit.

Of course, in the obligatory order part-time work is set up for: pregnant women; women with a child under the age of fourteen or a child with a disability; caring for a sick family member according to a medical opinion. None of these categories are students. But, for example, according to art. 1861 Labor Code guarantees, established by Art. 56 Labor Code, also apply to parents raising children without a mother (in particular, in case of prolonged stay of a mother in a hospital), as well as guardians (trustees), one of the foster parents, one of the parent-educators, which is possible for some students.

Persons who work part-time, enjoy the same rights as those who work under normal working hours. They are given a vacation of the same duration, provided weekends and holidays, the time of work is credited to the length of service. According to Art. 57 Labor Code the time for the beginning and end of daily work (change) is provided by the rules of the internal labor regulations and the schedules of variability in accordance with the legislation. According to Art. 142 Labor Code Rules of the internal labor 
regulations are approved by labor collectives on the basis of the submission of the owner or authorized by him and the elective body of the primary trade union organization (trade union representative) on the basis of standard rules. In addition, Art. 7 of the Law of Ukraine "On Collective Agreements and Agreements" dated July 1, 1993 No. 3356-XII stipulates that the obligations of the parties to regulate production, labor, socio-economic relations, in particular, with regard to the regime of work and the length of working time, are set out in a collective agreement.

Therefore, we emphasize once again that these issues should be written in an employment contract. When having a few jobs alternating the shifts must be uniform in accordance with the order established by the rules of internal labor regulations. Switching from one shift to another, as a rule, should take place every working week in hours defined by the variables. The duration of the interruption in the work between the changes must be not less than the duration of the working time twiced in the previous change (including the time of the break for lunch). The appointment of an employee to work during two changes in a row is prohibited (Articles 58, 59 of the Labor Code). In practice, unfortunately, these requirements are not fulfilled by the employer. And students do not follow the requirements regarding the length of the work shift. Themselves are begging a working day without interruptions, a few changes in a row. Of course, at their age, such a load is not yet reflected on health. More than once, students, having listened to several lectures, immediately go to work, then stay on the night shift, and in the morning, on classes, especially on the first, they try to sleep. Accordingly, about what kind of learning can be talked.

\section{Conclusions}

1. On the basis of the foregoing, we draw conclusions: the work of a student studying on a full-time form of study can not be regarded as a combination, that is because learning is not the main work of the student; student workers have the same labor rights and responsibilities as other employees; while employing first-year students, employers must monitor whether there are among them minors for whom the legislation provides special requirements for employment and fulfillment of labor duties; the student's work regime will depend on the schedule of training, and the wage will depend on the duration of the labor duties.

2. Based on Art. 7 of the Law of Ukraine "On Collective Contracts and Agreements", which stipulates that the obligations of the sides to regulate production, labor, socio-economic relations, in particular with regard to the regime of work and the length of working time, are set out in a collective agreement. Therefore, emphasizing once again that these issues should be voiced and written in an employment contract.

\section{References}

1. The Law of Ukraine "On Occupational Safety" in the wording of November 21, 2002.
2. The Law of Ukraine "On Compulsory State Social Insurance against Accident at Work and Occupational Disease that Caused Disability".

3. Legislation of Ukraine on labor protection (a collection of normative documents., 4 t. - K .: State Committee of Ukraine for Supervision of Labor Protection, Osnova, 1995.

4. The Law of Ukraine "On Education" No. 1060-XII of 23.05.1991 (subparagraph 14, paragraph 1, Article 51) and the Law of Ukraine "On Higher Education" dated July 1, 2014, No. 1556-VII (paragraph 3 of clause 1 Article 62)

5. Law of Ukraine "On Employment of the Population" of 1 March 1991 No. 803-XII

6. Article 15 of the Law of Ukraine "On Vacations" dated November 15, 1996 No. 504/96-VR).

7. The Code of Labor Laws of Ukraine (Revision of 10.11.2018, basis -2542-VIII)

(Article 2, Part 2 of Article 24, Articles 38, 39, 40, Part 1, Article 48, Article 50, Article 51, Part 1, Article 56, Article 94, Article 187- 200; st.201-204;) st.216-217; p.6 pp. 1 pp. 232; Part 6 of the Art. 235,238.

8. Art. 1 3У "About payment of labor" dated March 24, 1995, № 108/95-BP).

Part 1 of Art. 4 lesson № 5067-VI

9. pp. 7 clause 1 of Art. 1 Law of Ukraine "On Employment of the Population" dated 05.07.2012 No. 5067-VI (hereinafter - the Law № 5067-VI)

10. Letter of the Ministry of Social Policy of 05.05.2015 № 198/06 / 186-15.

11. Letter of the Ministry of Social Policy of Ukraine dated July 25, 2014 № 301/13 / 116-14

12. Letter from the State Department for Supervision of Compliance with the Labor Law of August 8, 2002, No. 010-777.

13. Clause 1.4. Instruction on the procedure for conducting work books of workers (approved by the order of the Ministry of Labor of Ukraine, Ministry of Justice of Ukraine, Ministry of Social Protection of the Population of Ukraine dated July 29, 1993 No. 58)

14. Letter from the State Department for Supervision of Compliance with the Labor Law of August 20, 2003 No. 013-1229-22

15. Resolution of the Plenary Session of the Supreme Court of Ukraine "On the Practice of the Application by the Courts of Labor Payments Legislation" of December 24, 1999, No. 13.

16. Part 3, Clause 14 of the Resolution of the Supreme Court of Ukraine "On the Practice of the Use by the Courts of the Law on Remuneration of Work" of December 24, 1999, No. 13.

17. Resolution of the Cabinet of Ministers of Ukraine dated 28 June 1997. No. 634 "On Approval of the Procedure, Duration and Conditions for the Provision of Annual Vacations for Workers Studying at Higher Educational Institutions with Evening and Extramural Forms of Education, where the educational process has its own peculiarities"

18. State sanitary norms and rules "Hygienic classification of labor on the indicators of harmfulness and danger factors of the production environment, the severity and intensity of the labor process", approved by the order of the Ministry of Health of Ukraine from 08.04.2014 number 248 . 
19. Order of the Ministry of Health of Ukraine of 25.05.2006 № 319.

20. Order of the Ministry of Labor and Social Policy of Ukraine dated March 23, 2001 №122

21. The procedure for the certification of workplaces under the terms of work, approved by the Cabinet of Ministers of Ukraine from 01.08.92, No. 442.

22. https://www.sop.com.ua/article/654-triandidrobochogo-

chasu?utm_source=Email\&utm_medium=letternews\&ut m_campaign=letternews_SOP02032018\&ustp=F

23. Fundamentals of labor protection: the textbook / Zaporozhets O.I.; ed. prof. OI Zaporozhets. Kyiv: Publishing Center of the Central Library, 2018. 264 p.

\section{Список літератури}

1. Закон України "Про охорону праці" в редакції від 21 листопада 2002 р.

2. Закон України "Про загальнообов'язкове державне соціальне страхування від нещасного випадку на виробництві та професійного захворювання, які спричинили втрату працездатності".

3. Законодавство України про охорону праці (збірник нормативних документів. У 4 т. К.: Держнаглядохоронпраці; Основа, 1995.

4. Законом України «Про освіту» від 23.05.1991 № 1060-XII (ч. 14 п. 1 ст. 51) та Законом України «Про вищу освіту» від 01.07.2014 № 1556-VII (пп. 3 п. 1 ст. 62).

5. Законом України «Про зайнятість населення» від 1 березня 1991 р. № 803-XII

6. ст.15Закону України «Про відпустки» від 15 листопада 1996 р. № 504/96-ВР).

7. Кодекс законів про працю України (Редакція від 11.10.2018, підстава -2542-VIII) (ст. 2; ч. 2 ст. 24; ст. $38,39,40$; ч. 1 ст. 48 ; ст. 50 ; ст. 51 ; ч. 1 ст. 56 ; ст. 94; ст. 187-200; ст.201-204; ) ст.216-217; п.6 ч. 1ст. 232; ч. 6 ст. 235,238 .

8. ст. 1 ЗУ «Про оплату праці» від 24.03.1995 № 108/95-ВР). ч. 1 ст. 4 3У № 5067-VI

9. пп. 7 п. 1 ст. 1 ЗУ «Про зайнятість населення» від 05.07.2012 № 5067-VI (далі - ЗУ № 5067-VI )

10. Лист Мінсоцполітики від 25.05.2015 № 198/06/186-15.

11. Лист Мінсоцполітики від 25.07.2014 № 301/13/116-14.

12. Лист Державного департаменту нагляду за додержанням законодавства про працю від 8 серпня 2002 р. № 010-777.

13. п. 1.4 Інструкція про порядок ведення трудових книжок працівників( затвердженої наказом Міністерства праці України, Міністерства юстиції України, Міністерства соціального захисту населення України від 29 липня 1993 р. № 58)

14. Лист Державного департаменту нагляду за додержанням законодавства про працю від 20 серпня 2003 р. № 013-1229-22

15. Постанова Пленуму Верховного Суду України «Про практику застосування судами законодавства про оплату праці» від 24 грудня 1999 р. № 13.
16. ч.3 п.14 постанови Верховного Суду України «Про практику застосування судами законодавства про оплату праці» від 24.12.1999.

17. Постанова Кабінету Міністрів України від 28 червня 1997p. № 634 «Про затвердження Порядку, тривалості та умов надання щорічних відпусток працівникам, які навчаються у вищих навчальних закладах з вечірньою та заочною формами навчання, де навчальний процес має свої особливості»

18. Державні санітарні норми та правила «Гігієнічна класифікація праці за показниками шкідливості та небезпечності факторів виробничого середовища, важкості та напруженості трудового процесу», затверджені наказом МО3 України від 08.04.2014 № 248.

19. Наказ Міністерства охорони здоров'я України від 25.05.2006 № 319 .

20. Наказ Міністерства праці та соціальної політики України від 23.03.2001 №122.

21. Порядок проведення атестації робочих місць за умовами праці, затвердженого постановою Кабінету Міністрів України від 01.08.92 № 442.

22. https://www.sop.com.ua/article/654-trivalstrobochogo-

chasu?utm_source=Email\&utm_medium=letternews\&ut m_campaign=letternews_SOP02032018\&ustp=F

23. Основи охорони праці: підручник. Запорожець O.I; за ред. проф. О.І. Запорожця. Київ: Видавничий центр ЦУЛ, 2018. 264 с.

\section{ПРАЦЕВЛАШТУВАННЯ СТУДЕНТІВ ВНЗ У ПОРІВНЯННІ 3 НОРМАТИВНИМ \\ РЕГУЛЮВАННЯМ ПРАЦЕВЛАШУВАННЯ}

Л. Е. Піскунова, Т. О. Зубок, Б. В. Кислицький

Анотація. Розглянуто кілька найпоширеніших ситуацій, які на практиці найчастіше викликають питання правового характеру щодо регулювання трудових правовідносин зі студентами, які поєднують роботу з навчанням.

Приймати студента денної форми за сумісництвом чи вважати підприємство основним місцем його роботи? Питання є принциповим, оскільки пов'язане із веденням трудової книжки.

Під час навчання між студентами денної форми навчання i навчальними закладами не виникають трудові стосунки і не підписується трудовий договір. Тому таке навчання не є основною роботою студента.

Неповнолітні студенти- працівники мають такі самі трудові права та обов'язки, як і інші працівники.

Ключові слова: Кодекс законів про працю України, Державний департамент нагляду за додержанням законодавства про працю, Інструкції про порядок ведення трудових книжок, трудове законодавство, робота за трудовим договором, трудова книжка, сумісництво, грошовий вираз, працевлаштування неповнолітніх, НУБіП України.

\section{РАБОТОУСТРОЙСТВО СТУДЕНТОВ ВУЗ В СРАВНЕНИИ С НОРМАТИВНЫМ РЕГУЛИРОВАНИЕМ}

Л. Е. Пискунова, Т. О. Зубок, Б. В. Кислиџкий 
Аннотация. Рассмотрены несколько распространённых ситуаций, которые на практике чаще всего вызывают вопрос правового характера по поводу регулирования трудовых отношений со студентами, которые объединяют работу с учебой. Принимать студента дневной формы по совместительству или считать предприятие основным местом его работы? Вопрос очень важен, поскольку связан с ведением трудовой книги.

Во время учёбы между студентами дневной формы обучения и учебными заведениями не возникают трудовые отношения и не заключается трудовой договор. Поэтому такое обучение не является основной работой студента.

Несовершеннолетние студенты-работники имеют такие же трудовые права и обязанности, как и другие работники.

Ключевые слова: Кодекс законов о труде Украины, Государственный департамент надзора за соблюдением законодательства о труде, Инструкции о порядке ведения трудовых книжек, трудовое законодательство, работа по трудовому договору, трудовая книжка, совместительство, денежное выражение, трудоустройство несовершеннолетних.

Л. Е. Піскунова ORCID 0000-0002-6297-587X.

T. О. Зубок ORCID 0000-0001-8217-866X.

Б. В. Кислицький ORCID 0000-0001-6258-189X. 